\title{
Communication
}

[Comunicação]

\section{Ostrich (Struthio camelus) gastric diseases in Minas Gerais, Brazil, from 1997 to 2009}

(Doenças gástricas de avestruzes em Minas Gerais)

\author{
J.F.P. Mendonça ${ }^{1}$, S.Q. Lopes $^{2}$, A. Aichinger ${ }^{2}$, A.C. Horta ${ }^{2}$, A.M. Siqueira ${ }^{3}$, \\ L.B. Carvalho ${ }^{4}$, J.S. Resende ${ }^{5}$, N.R.S. Martins ${ }^{5^{*}}$ \\ ${ }^{1}$ Aluna de pós-graduação - UnB - Brasília, DF \\ ${ }^{2}$ Médico veterinário \\ ${ }^{3}$ IBAMA - Belo Horizonte, MG \\ ${ }^{4}$ MAPA - Brasília, DF \\ ${ }^{5}$ Escola de Veterinária - UFMG \\ Av. Antonio Carlos, 6627 \\ 31270-901 - Belo Horizonte, MG
}

In ostrich farming, gastric diseases are usual causes of increased mortality and economic losses. Infectious and non-infectious pathogens can damage the gastrointestinal tract, affecting the digestive process. Gastric impaction may be characterized by anorexia, cachexia, dehydration, apathy, decubitus, and dry and reduced feces. Chronic anorexia result in progressive loss on the reproductive performance and may culminate in death, causing significant economic losses in ostrich farms (Gulbahar et al,. 2000; Yusek et al., 2002; Komnenou et al., 2003).

This paper presents the ostrich gastric dysfunctions diagnosed at the Escola de Veterinária at the Universidade Federal de Minas Gerais, from 1997 to 2009, and the preventive strategies recommended. Clinical records with data of necropsies, clinical and laboratory results collected from 1997 to 2009 were divided into general and gastrointestinal dysfunctions, which were classified into impaction and infectious and parasitic gastritis.

According to the clinical records analyzed, $46.2 \%$ of diagnosed dysfunctions in ostriches were gastroenteric diseases and $53.9 \%$ were dysfunctions of various origins. Among the gastrointestinal conditions, $83.3 \%$ were gastric impaction and $16.7 \%$ infectious or parasitic gastritis caused by megabacteria and/or Libyostrongylus douglassii.

Recebido em 22 de fevereiro de 2010

Aceito em 4 de outubro de 2010

*Autor para correspondência (corresponding author)

E-mail: nrsmart@gmail.com
Gastric impaction was characterized by chronic anorexia and the clinical description of cachexia, dehydration, apathy, decubitus, and dry and scanty feces. As described in literature, chronic anorexia may eventually result in death, being a cause of productive loss and inferior reproductive performance (Gulbahar et al., 2000; Yusek et al., 2002; Komnenou et al., 2003). At necropsy, undigested material and foreign bodies (hair, metal rings, feathers, leaves, seeds, hooks, bones, stones, glasses, and sand) were observed in ostriches proventriculus and/or ventricle (Figure 1a, 1b, 1c, and 1d), as previously described by Mushi et al. (1998), Martins et al. (2006), and Aichinger (2007). Erosions, ulcers, and bleeding were observed in proventriculus and ventricle (Figure 1e), as well as mucosal edema and necrosis, similar to previous reports (Crabill and Honnas, 1996; Gulbahar et al., 2000; Yusek et al., 2002). Peritonitis (Figure $1 \mathrm{~g}$ ) due to ingestion of sharps, leading to perforation of the gastrointestinal tract and abdominal distension, was also observed (Figure 1h). Gastric impaction in ostriches occurs mainly by access to foreign materials which should not be within the reach of animals and / or as a result of behavioral problems which reflect errors in the flock management, including stressful conditions, animal translocation or ambient change, poor sources or low fiber nutrition, sudden changes in feeding schedule and/or 
composition, changes in bedding or introduction of it for adult animals, lack of space for handling, and high density of animals (Sato et al., 1994; Shwaluk and Finley, 1995; Gulbahar et al., 2000; Yusek et al., 2002). Besides, the hipocontractility of gastrointestinal tract smooth muscle may be an important contributing factor related to nutritional and primary management causes (Speer, 1996).

Regarding infectious and parasitic gastritis, $M$. ornithogaster and $L$. douglassii were the most diagnosed pathogens and accounted for $16.7 \%$ of the gastric diseases causes during the analyzed period. Cachexia, conjunctival and mucosal paleness, and extreme prostration were observed in gastritis by $M$. ornithogaster in animals treated during the study period. At necropsy, distended flaccid heart; coronary fat atrophy (Figure 1i); proventriculus and gizzard distended by food, initially without impaction; and mucosal erosions, ulcers (Figure 1j), and bleeding were noted. Infections by $M$. ornithogaster can produce gastric changes similar to those observed in impaction and require laboratory diagnosis. Impressions of the ventricular coilin membrane and subcoilin mucosa and proventriculus mucosa were made on glass slide and observed under light microscopy (100 and $400 x$ ) for differential diagnosis, enabling the visualization of typical large rods (Huchzermeyer et al., 1993; Martins et al., 2006), bacillary structures visible from 100 times magnification and without staining (Figure $1 \mathrm{k}$ ). At microscopy, rods are easily visible on the proventriculus and gizzard, but for the inspection of fecal material, should be visualized first at 100x magnification for avoiding confusion with large filamentous bacteria which are motile, thinner, and longer. This type of confusion occurred in a previous report (Martins et al., 2006). Parasitic gastritis by L. douglasii was the most consistently detected helminth-associated gastric lesions in ostriches during the period. Clinical signs included apathy, loss of appetite, and pallor, indicating anemia which, according to the literature, is associated to these burrowing parasites digging into the inner lining of proventriculus and gizzard, sucking blood, and causing a severe inflammatory reaction, resulting in the death of young individuals (Gordo et al., 2002). Larvae of the parasite were observed at coproculture, and eggs were observed in stools (Figure 1 1). At necropsy, hemorrhagic erosions, ulcers, mucosal edema, and mucus were found, similar to previous reports (Crabill and Honnas, 1996; Gulbahar et al., 2000; Yusek et al., 2002).

The casuistic of ostrich diseases here reported reflects the perception of farmers and may indicate inadequate farming, possibly representing aggravated conditions. Gastric disorders important to ostrich farming in Minas Gerais were present and their prevention may include the adoption of good farming practices, namely the provision of adequate nutritional requirements, permanent monitoring for quality raising ambient, designed to ensure biosecurity, welfare, and technical assistance with laboratory diagnosis.

Keywords: ostrich, gastric impaction, Macrorhabdus ornithogaster, Libyostrongyllus douglassii, Brazil

\section{RESUMO}

Descrevem-se as doenças gástricas de avestruzes diagnosticadas em um Laboratório de Doenças das Aves, Belo Horizonte-MG, entre 1997 e 2009. As afecções gástricas corresponderam a 46,2\% de todos os casos de doença, com quadros que incluíram impactação (83,3\%), infecções e parasitoses (16,7\%). As impactações foram causadas por material não alimentar diversificado $e$ as infecções e parasitoses incluíram o fungo Macrorhabdus ornithogaster (megabacteria) e o nematódeo Libyostrongylus douglassii.

Palavras-chave: avestruz, impactação gástrica, Macrorhabdus ornithogaster, Libyostrongyllus douglassii, Brasil 


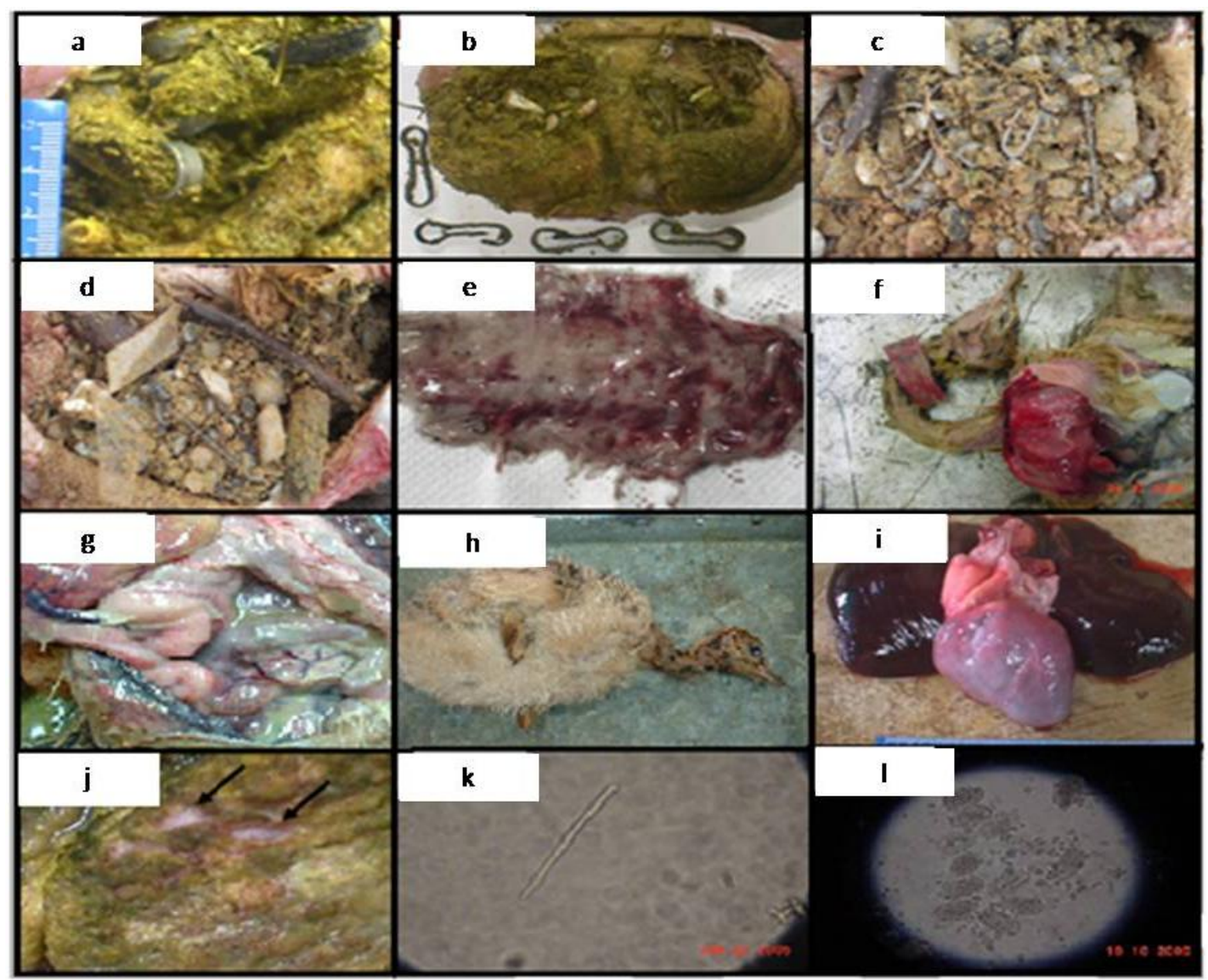

Figure 1. Ostrich gastric impaction, necropsy findings of non-food materials and infectious and parasitic etiologies in proventriculus and gizzard are shown. a) metal rings; b) hooks, bones; c, d) stones, glass, seeds, sand; wire fragments; twigs e) haemorhagic proventriculus; f) proventricular bleeding; g) peritonitis; h) abdominal distention; i) Macrorhabdosis ("Megabacteriosis") in ostrich; coronarian fat atrophy and flaccid heart; j) Macrorhabdosis; recent ulcerative lesions on the ventricular mucosa of a 5month-old ostrich; observe epithelial perforation into submucosa (arrows); k) Macrorhabdus ornithogaster at optical microscopy without staining (400x). 1) Libyostrongilosis in ostrich. Libyostrongylus douglassi eggs (400x).

\section{REFERENCES}

AICHINGER, A. Impactação de proventrículo e ventrículo por corpos estranhos em avestruzes. Rev. Acad., v.5, p.311-315, 2007.

CRABILL, M.R.; HONNAS, C.M. Surgical conditions of ratites. In: TULLY Jr., T.N.; SHANE, S.M. (Eds). Ratite: management, medicine and surgery. Malabar, FL: Krieger Publishing Company, 1996.

GORDO, P.F.; HERRERA, S.; CASTRO, A.T. et al. Parasites from farmed ostriches (Struthio camelus) and rheas (Rhea americana) in Europe. Vet. Rec., v.107, p.137-160, 2002.
GULBAHAR, M.; AGAOGLUB, Z.; BIYIK, H. et al. Zycomycotic proventriculitis and ventriculitis is ostriches (Struthio camelus) with impaction. Aust. Vet. J., v.78, p.247-249, 2000.

HUCHZERMEYER, F.W. Diseases of farmed crocodiles and ostriches. Rev. Sci. Tech., v.21, p.265-76, 2002.

KOMNENOU, A.T.; GEORGIADES, G.K.; SAVVAS, I. et al. Surgical treatment of gastric impaction in farmed ostriches. J. Vet. Med., v.50, p.474-477, 2003. 
MARTINS, N.R.S.; HORTA, A.C.; SIQUEIRA, A.M. et al. Macrorhabdus ornithogaster in ostrich, rhea, canary, zebra finch, free range chicken, turkey, guinea-fowl, columbina pigeon, toucan, chuckar partridge and experimental infection in chicken, japanese quail and mice. Arq. Bras. Med. Vet. Zootec., v.58, p.291-298, 2006.

MUSHI, E.Z.; ISA, J.F.; CHABO, R.G. et al. Impaction of the stomachs in farmed ostriches (Struthio camelus) in Botswana. Avian Dis., v.42, p.597-9, 1998.

SATO, Y.; YASUSA, J.; SINSUNGWE, H. et al. An occurrence of stomach impaction in ostriches (Struthio camelus) on a farm in Zambia associated with high mortality. J. Vet. Med. Sci., v.56, p.783-784, 1994.
SHWALUK, T.W.; FINLEY, D.A. Proventricular-ventricular impaction in an ostrich chick. Can. Vet. J., v.36, p.108-109, 1995.

SPEER, B.L. Developmental problems in young ratites. In: TULLY Jr., T.N.; SHANE, S.M. (Eds). Ratite: management, medicine and surgery. Malabar, FL: Krieger Publishing Company, 1996.

YÜKSEK, N.; AGAOGLU, Z.; KAYA, A. et al. Stomach impaction in ostriches (Struthio camelus): blood chemistry, hematology and treatment. Avian Dis., v.46, p.757-760, 2002. 